\title{
A cold-sensitive mRNA splicing mutant is a member of the RNA helicase gene family
}

\author{
Evelyn J. Strauss and Christine Guthrie \\ Department of Biochemistry and Biophysics, University of California, San Francisco, California 94143 USA
}

\begin{abstract}
We have isolated a cold-sensitive mutant of Saccharomyces cerevisiae in which the first step of mRNA splicing is inhibited. The growth and splicing defects are recessive and cosegregate, thus defining a single essential gene (PRP28). The wild-type PRP28 gene was cloned, and sequence analysis reveals extensive homology to a family of proteins that are thought to function as ATP-dependent RNA helicases. The cold sensitivity is caused by a glycine-to-glutamic acid change in a conserved sequence motif. Interestingly, double mutants containing conditional alleles of PRP28 and PRP24, which encodes a U6 snRNA-binding protein, are inviable. In addition, a suppressor of prp28-1 is a mutant allele of PRP8, which encodes a U5 protein, thus linking PRP28 with U5. These data are consistent with a scenario in which PRP28 acts to unwind the U4/U6 base-pairing interaction in the U4/U6/U5 snRNP, facilitating the first covalent step of splicing.
\end{abstract}

[Key Words: Splicing; helicase; S. cerevisiae]

Received December 7, 1990; revised version accepted January 18, 1991.

The removal of introns from nuclear mRNA precursors proceeds via two consecutive trans-esterification reactions. In the first step, the $5^{\prime}$ splice site is cleaved, and a lariat intron- $3^{\prime}$ exon intermediate is formed. This is followed by 3 ' splice site cleavage and exon ligation, with the release of the intron in lariat form (for review, see Green 1986; Padgett et al. 1986). The reaction requires five U snRNAs (for review, see Maniatis and Reed 1987; Sharp 1987; Guthrie and Patterson 1988; Steitz et al. 1988 ) and an as yet undetermined number of proteins, some of which are integral small nuclear ribonucleoprotein (snRNP) components. In yeast, at least 20 of these proteins have been identified by genetic means (premRNA processing mutants: prp2-prp9, prp11, prp16prp27) (Hartwell 1967; Hartwell et al. 1970; Vijayraghavan et al. 1989).

mRNA splicing occurs in a large complex called the spliceosome (Brody and Abelson 1985; Frendewey and Keller 1985; Grabowski et al. 1985; for review, see Green 1986; Padgett et al. 1986). Spliceosome assembly is a dynamic process, involving the ordered formation and severing of multiple interactions between snRNPs, proteins, and the pre-mRNA. In yeast, the first detectable event is the formation of a committed complex that requires the U1 snRNP and intact $5^{\prime}$ splice site and branchpoint sequences (Ruby and Abelson 1988; Seraphin and Rosbash 1989). After U1 associates with the pre-mRNA, U2 binds to the branchpoint, followed by addition of U4/U6 and U5 (Pikielny et al. 1986; Cheng and Abelson 1987). It has been shown that the U4/U6 and U5 snRNPs associate stably with each other: They comigrate on glycerol gradients and in native gel electrophoresis (Bindereif and Green 1987; Cheng and Abelson 1987; Konarska and Sharp 1987); and in Saccharomyces cerevisiae, immunoprecipitation of a U5 protein, PRP8, coprecipitates U4 and U6 in an ATP-dependent fashion (Lossky et al. 1987). It is thought that U4, U5, and U6 join the spliceosome as a tripartite complex. Formation of the tri-snRNP complex requires the U4-associated protein PRP4 (Banroques and Abelson 1989; Xu et al. 1990) and appears to be an essential intermediate in the splicing pathway (Bordonné et al. 1990).

The U4/U6 snRNP is held together by two intermolecular helices, totaling 24 bp (Bringmann et al. 1984; Hashimoto et al. 1984; Siliciano et al. 1987b; Brow and Guthrie 1988). Prior to the first nucleolytic step of splicing, the particle undergoes a major conformational change, such that $\mathrm{U} 4$ is no longer associated with the spliceosome upon electrophoresis under nondenaturing conditions (Pikielny et al. 1986; Cheng and Abelson 1987; Lamond et al. 1988). Given that the native U4/U6 snRNP in yeast has a melting temperature of $53^{\circ} \mathrm{C}$ (Brow and Guthrie 1988), the destabilization is presumed to require an active process. Notably, ATP is required at most steps in the in vitro pathway (Brody and Abelson 1985; Lin et al. 1987; Sawa et al. 1988; Vijayraghavan and Abelson 1990; Schwer and Guthrie 19911, and a number of splicing proteins have recently been shown to contain putative ATP-binding domains (Burgess et al. 1990; Dalbadie-McFarland and Abelson 1990). Thus, a 
major goal in understanding splicing is elucidating the mechanisms of conformational rearrangements during assembly of the spliceosome.

We set out to identify new trans-acting factors involved in mRNA splicing in $S$. cerevisiae. In particular, we were interested in generating cold-sensitive splicing mutants for two reasons. First, macromolecular assembly processes are likely to be particularly sensitive to cold. It has been argued on thermodynamic grounds that in general, mutational defects affecting assembly processes may be intensified at low temperatures due to the largely hydrophobic nature of the interactions driving these reactions (Cantor and Schimmel 1980). This predisposition to cold sensitivity has been borne out for the biopolymers tubulin and actin (Huffaker and Botstein 1988, Novick et al. 1989), as well as phage head structures (Jarvik and Botstein 1975) and ribosomal proteins (Guthrie et al. 1969; Tai et al. 1969), for which many cold-sensitive alleles have been found. Second, some gene products are inherently more likely to mutate to cold rather than heat sensitivity. There are some genes for which multiple cold-sensitive alleles, but no temperature-sensitive alleles (and vice versa), have been isolated. The cell division cycle $(c d c)$ class of mutants illustrate this point (Moir et al. 1982). Therefore, the genetic target set for cold sensitivity is likely to differ from that for temperature sensitivity. We thus hoped to find cold-sensitive splicing mutants defective in spliceosome assembly that would shed light on functional interactions between the components of the splicing machinery.

Here, we report the isolation of a cold-sensitive splicing mutant that defines a member of a putative ATPdependent RNA helicase gene family. These proteins are thought to unwind RNA in an ATP-dependent fashion, on the basis of the in vitro activity of the founding member eIF4A (Rozen et al. 1990). As a first step toward determining the function of this protein, we looked for genetic interactions with other splicing factors. The results from this analysis point to a functional relationship between this protein and the U4/U6/U5 snRNP. This protein is an excellent candidate for catalyzing the destabilization of $\mathrm{U} 4 / \mathrm{U} 6$, thus facilitating the first covalent step of splicing.

\section{Results}

\section{Isolation of a cold-sensitive splicing mutant}

Wild-type haploid yeast cells were UV-mutagenized to $1 \%$ survival. Following growth at $25^{\circ} \mathrm{C}$, the colonies formed by survivors were replica-plated and incubated at $16^{\circ} \mathrm{C}$ and $37^{\circ} \mathrm{C}$. Isolates with conditional growth phenotypes were identified: Of 3000 candidates, 18 were coldsensitive and 31 were temperature-sensitive.

To test whether any of these conditional mutants had splicing defects, primer extension analysis was carried out on RNA obtained after growth to mid-log phase at $25^{\circ} \mathrm{C}$, followed by a shift to the nonpermissive temperature for one to two generations. We used a primer specific to the intron-containing MATa1 gene that enabled us to detect pre-mRNA, mRNA, and splicing intermediates. One cold-sensitive strain and three of the temperature-sensitive strains accumulated pre-mRNA relative to a wild-type control, while one temperature-sensitive candidate accumulated lariat intermediate (data not shown).

We subsequently carried out primer extension analysis using primers to two other spliced genes to determine the generality of the splicing defect. The results for the cold-sensitive mutant (called csl) and, for comparison, two of the temperature-sensitive mutants, are shown in Figure 1. The ratio of pre-mRNA/mRNA increases /relative to a wild-type strain| for CYH2 and $R P 73$, as well as for MATa1 (data not shown and Fig. 2). This result indicates that the mutations reside in genes encoding elements of the generic splicing apparatus.

To determine whether the growth and splicing defects of csl were due to the same mutation, we analyzed a cross between csl and a wild-type strain. The heterozygous diploid was cold-insensitive and displayed no splicing defect, demonstrating that both phenotypes are recessive. Of 18 four-spored tetrads all 18 yielded two coldsensitive and two $\mathrm{cs}^{+}$spores, indicating the segregation of a single gene. We have named this locus PRP28 (see below). RNA from nine random spores that were grown under the same conditions as the original mutant was

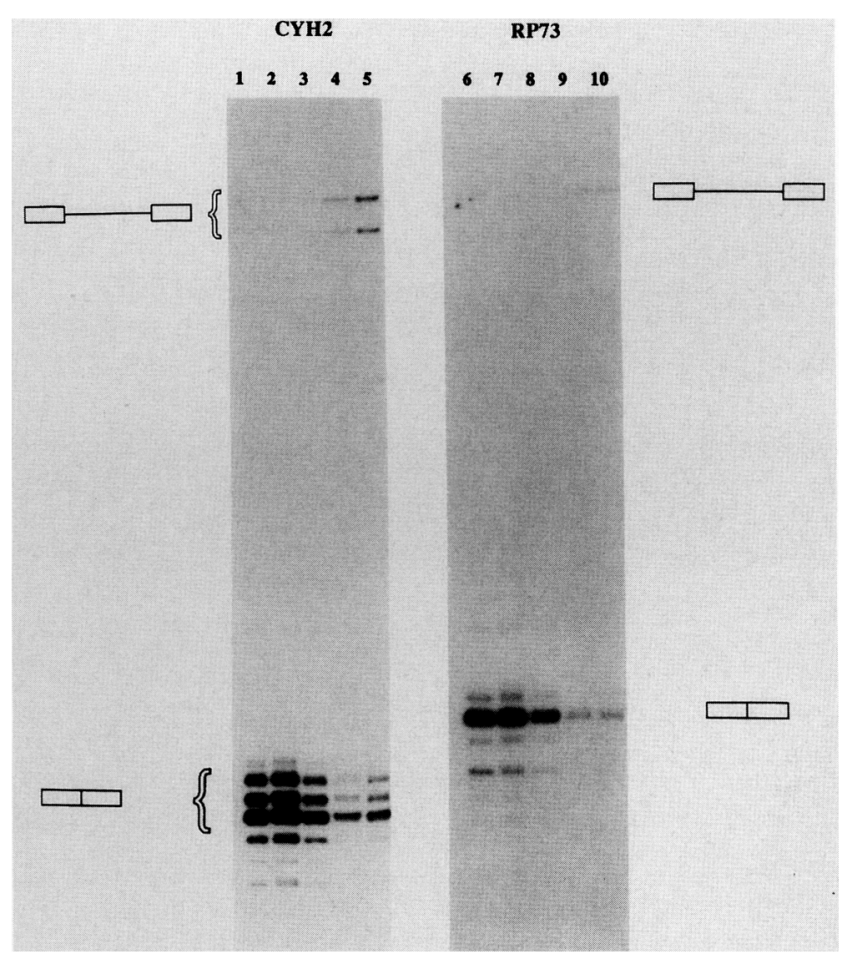

Figure 1. Primer extension of RNA from mutant and wild-type strains. (Left) CYH2; (right) RP73. Cells were grown as stated in text. Positions of precursor and mature mRNAs are indicated. (Lanes 1 and 6 ) Wild-type, $16^{\circ} \mathrm{C}$; (lanes 2 and 7) cs2 (a coldsensitive strain that does not exhibit a splicing phenotypel, $16^{\circ} \mathrm{C}$; (lanes 3 and 8 ) ts $1,37^{\circ} \mathrm{C}$; (lanes 4 and 9) ts $2,37^{\circ} \mathrm{C}$; (lanes 5 and 10$) \mathrm{csl}, 16^{\circ} \mathrm{C}$. 


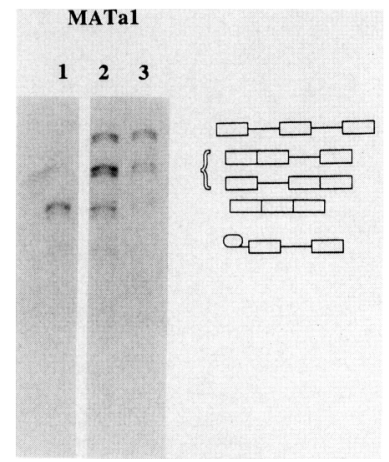

Figure 2. Primer extension of MATa1 RNA from csl grown at different temperatures. (Lane 1) Wild-type, $16^{\circ} \mathrm{C}$; (lane 2) csl, $25^{\circ} \mathrm{C}$; (lane 3 ) $\operatorname{cs~} 1,16^{\circ} \mathrm{C}$.

assayed by primer extension analysis. The two cold-sensitive spores accumulated pre-mRNA while the seven $\mathrm{cs}^{+}$spores were wild-type for splicing. These results suggest that a single mutant gene (prp28-1) gives rise to both the splicing and growth phenotypes. Biochemical linkage between cold sensitivity and splicing was established by comparing primer extensions of RNA extracted from cs1 grown under permissive conditions with RNA obtained from the cold-shifted cultures (Fig. 2). At $25^{\circ} \mathrm{C}$, a temperature at which csl strains are slightly impaired for growth relative to wild type, splicing is somewhat inhibited (cf. lanes 1 and 2). However, after incubation at $16^{\circ} \mathrm{C}$ there is a substantial increase in the ratio of premRNA/mRNA (lane 3). This result suggests that the cold sensitivity reflects the block in splicing. Only cs1 splices inefficiently: Cold-sensitive growth does not generally result in aberrant splicing (e.g., Fig. 1, lanes 2 and 7 are primer extensions of RNA extracted from a coldsensitive strain, cs2, that is inviable at $16^{\circ} \mathrm{C}$ but splices efficiently).

To determine the kinetics of onset of the prp28-1 growth defect, we monitored the growth rate after a shift to the nonpermissive temperature. In general, shutting off the synthesis of essential, relatively stable proteins and snRNAs results in a lag before growth rate slows. For example, a strain in which the synthesis of U5 RNA is arrested grows unhindered for six generations (Patterson and Guthrie 1987). Similarly, arresting synthesis of PRP16, a protein directly involved in splicing (Schwer and Guthrie 1991), results in impaired growth beginning only after 10 generations (S. Burgess and C. Guthrie, unpubl.). In contrast, conditionally lethal mutations in the coding region of U5 or PRP16 inhibit growth within one generation of the shift to the nonpermissive temperature (D. Frank and C. Guthrie; S. Burgess and C. Guthrie; both unpubl.). As shown in Figure 3, the doubling times for csl and a wild-type strain are indistinguishable at $30^{\circ} \mathrm{C}$ but diverge almost immediately after shifting to $17^{\circ} \mathrm{C}$. Within two generations csl exhibits its terminal growth phenotype: The doubling time is eight times that of wild type. The observed kinetics are consistent with the interpretation that the prp28-1 mutation confers a direct splicing defect. Alternatively, the mutation may interfere with the synthesis, modification, or folding of a very short-lived splicing factor.

\section{PRP28 defines a new splicing gene}

As described in the introductory section, temperaturesensitive mutations in factors involved in splicing define 18 complementation groups (Hartwell et al. 1970; Vijayraghavan et al. 1989). We carried out complementation and allelism tests between cs1 and prp2-prp8 and prp11 strains. In all cases, we obtained temperature-sensitive/ cold-sensitive double mutant spores, as well as each single mutant and wild-type spores. This indicates that the mutations segregate independently and thus reside in different genes. We then asked for rescue of the cold sensitivity with wild-type clones for snRNA genes SNR19 (U1), SNR20 (U2), SNR14 (U4), SNR7 (U5), and SNR6 (U6). All transformants remained cold-sensitive, indicating that the wild-type snRNAs do not complement the cs1 lesion. Finally, the wild-type PRP28 clone (see below) was transformed into prp16-prp24 and prp27 strains and tested for ability to rescue the conditional lethal phenotype of these strains. None of the transfor-

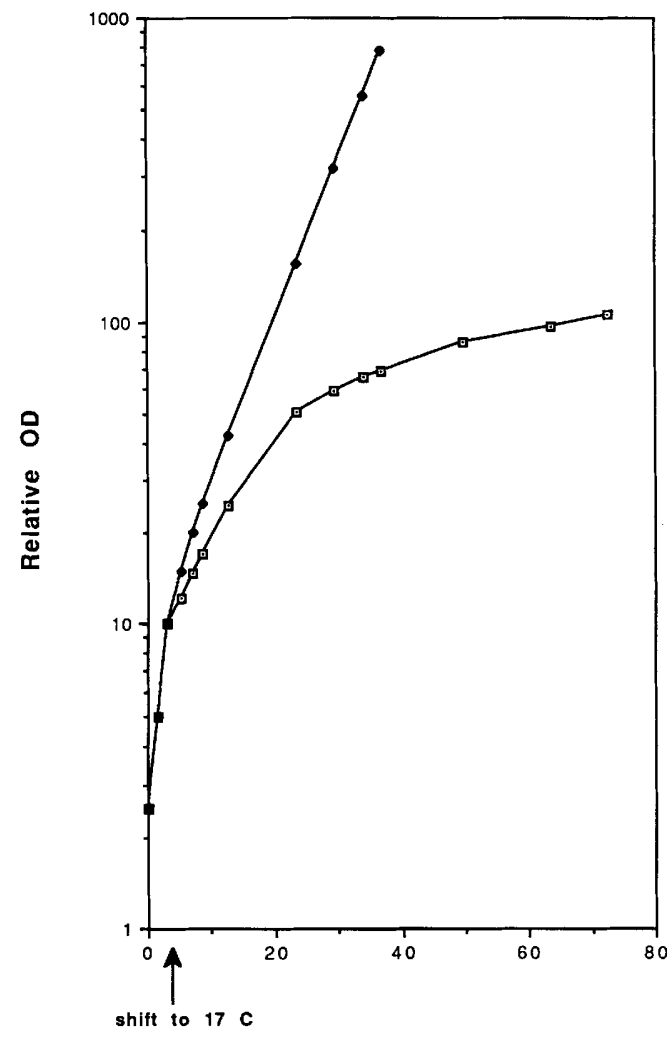

TIME (Hours)

Figure 3. Growth curve of cs1 (ब) and wild-type strains ( $\square$ ). Cultures were grown at $30^{\circ} \mathrm{C}$ to early log phase and shifted to $17^{\circ} \mathrm{C}$ (indicated by arrow). 


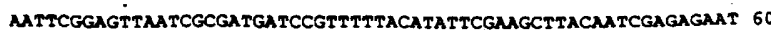
TACCAACGACAATAGMTTITTGACMACGMMAGGTCMATAGGAGCCGMigauTtAACAT 120

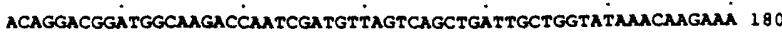
$M A R$ P I D V S O I I A G I N K K 17 AAMGGACTAGATGAAAATACATCAGGTAAAATCAGCAAGCCTAGgTtTTTGAATAAACAA 240

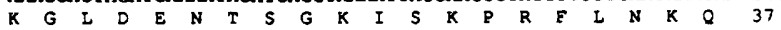
BgIII GAAGGATTAAGCAAGAACGTTTGAAGGAGACGAAGAGAGTTTGACGCCTACGCAAAGT 300

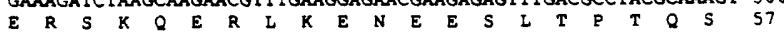

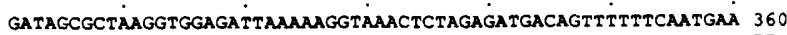
$\begin{array}{llllllllllllllllllll}D & \text { S } & K & \text { V } & \text { E I } & K & K & \text { V } & \text { N } & \text { S } & \text { R } & \text { D } & \text { D } & \text { S } & \text { E } & \text { E } & \text { N } & E & 77\end{array}$

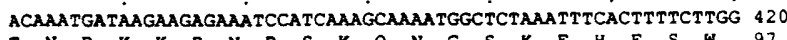
$\begin{array}{llllllllllllllllllllll}T & N & D & K & K & R & N & P & S & K & Q & N & G & S & K & F & H & F & S & W & 97\end{array}$

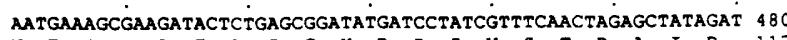
$\begin{array}{lllllllllllllllllllll}\text { N } & E & S & E & D & T & \text { L } & \text { S } & G & \text { Y } & \text { D } & \text { P } & \text { I } & \text { V } & \text { S } & \text { T } & R & \text { A } & \text { I } & \text { D } & 117\end{array}$ Pst I

TTGCTATGGAAGGGAAGACTCCTAAAAATGCTGCAGAATCTTCATATATGGGGAAGCAT 540 L L W K G K T F K N A A E S S Y M G K H

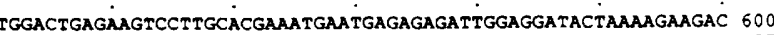
W T E K S I H E M N SacI

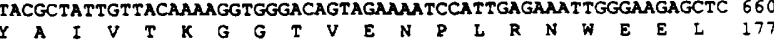
aAtatalacCaAggactigttacgtgtiattatacagGagctgcGatticcttcacca 720 $\begin{array}{lllllllllllllllllllll}\text { N } & I & I & \mathbf{P} & \mathbf{R} & \mathbf{D} & \mathbf{L} & \mathbf{I} & \mathbf{R} & \mathbf{V} & \text { I } & \text { I } & \mathbf{Q} & \mathbf{E} & \mathbf{L} & \mathbf{R} & \mathbf{F} & \mathbf{P} & \mathbf{S} & \mathbf{P} & 197\end{array}$

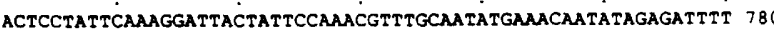
$\begin{array}{llllllllllllllllllllll} & \mathbf{T} & \mathbf{P} & \mathbf{I} & \mathbf{Q} & \mathbf{R} & \mathbf{I} & \mathbf{T} & \mathbf{I} & \mathbf{P} & \mathbf{N} & \mathbf{V} & \mathbf{C} & \mathbf{N} & \mathbf{M} & \mathbf{K} & \mathbf{Q} & \mathbf{X} & \mathbf{R} & \mathbf{D} & \mathbf{E} & 217\end{array}$ CTTGGTGTIGCCTCTACAGGTTCGGGTAAGACTTTGGCCTTTGTAATACCGATACTAATC 840 $\begin{array}{lllllllllllllllllllll}\text { I } & G & \text { V } & \text { A } & \text { S } & \text { T } & \text { G } & \text { S } & \text { G } & \text { K } & \text { T } & \text { I } & \text { A } & \text { F } & \text { V } & \text { I } & \text { P } & \text { I } & \text { L } & \text { I } & 237\end{array}$ BsteII MAGATGAGTAGGTCACCTCCMAGGCCACCATCTTTGMAGATTATTGATGGCCCCAAGCG 900

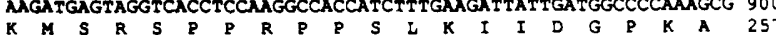

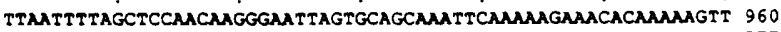

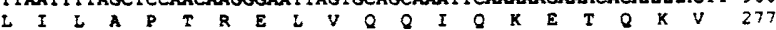
*A* ACAMAMTATGgTCCAAMGAGACAACTATGACTGCAAAGTAATTTCTATTGTTGGTGGA 1020

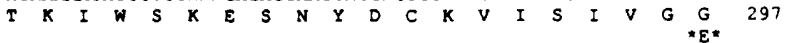
MscI CACTCCTTGGAGGNATTTCATTTTCTCTATCGGAGGGTTGTGACATCCTGGTGGCCACT 1080 $\begin{array}{lllllllllllllllllllll}\text { H } & S & \text { I } & E & E & \text { I } & S & \text { F } & \text { S } & \text { L } & \text { S } & \text { E } & \text { G } & \text { C } & \text { D } & \text { I } & \text { L } & \text { V } & \text { A } & \text { T } & 317\end{array}$

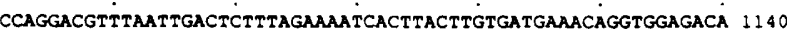
$\begin{array}{lllllllllllllllllllll}P & G & R & \text { L } & \text { I } & D & S & \text { L } & \text { E } & \text { N } & \text { H } & \text { L } & \text { L } & \text { V } & \text { M } & \text { K } & \text { Q } & \text { V } & \text { E } & \text { T } & 337\end{array}$ RsaI.

TTAGTACTAGATGAAGCTGACAMATGATTGATTTAGGTTTTGAGGACCAAGTAACAAAC 1200 L V I D E A D K M I D E G

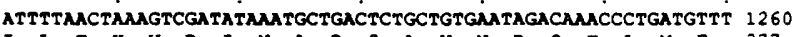

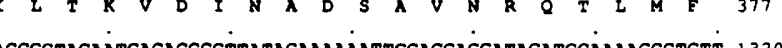
T A T M T P V I E K I A A G Y M Q K P V 397 SATGCMCCATTGGGTTGAGACGGGTTCTGMCCTTTGATTCAACAGGTTGTGGAATA 1380

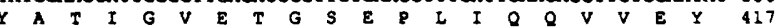

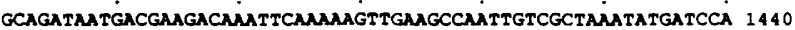
$\begin{array}{lllllllllllllllllllll}A & D & N & D & E & D & K & E & K & K & \text { L } & K & P & I & \text { V } & \text { A } & \text { K } & \text { Y } & \text { D } & \text { P } & 437\end{array}$

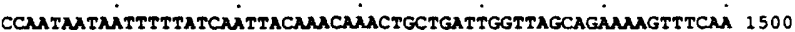

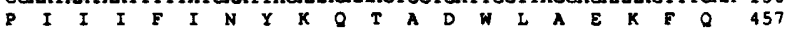

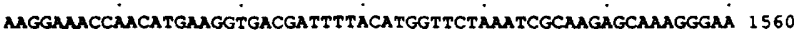
$\begin{array}{lllllllllllllllllllll}K & E & T & N & M & K & V & T & I & \text { L } & H & G & S & K & S & Q & E & Q & R & E & 477\end{array}$ CATtCTtTGCAATTATtTCGCACCAACAAAGTCCAAATCATGATCGCAACAAACGTTGCC 1620 $\begin{array}{lllllllllllllllllllll}\text { H S } & \text { I } & Q & \text { L } & \text { F } & \text { R } & \text { T } & \text { N } & \text { K } & \text { V } & \text { Q } & \text { I } & \text { M } & \text { I } & \text { A } & \text { T } & \text { N } & \text { V } & \text { A } & 497\end{array}$ ECORV GCAAGAGGATTGGATATCCCTAATGTTTCCTTGGTAGTCAATTTCCAGATTTCCAAAAA 1680

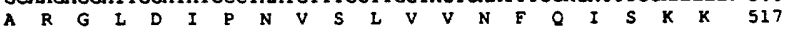

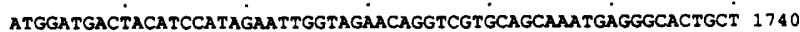
$\begin{array}{lllllllllllllllllllll}M & D & D & Y & I & H & R & I & G & R & \text { I } & G & R & A & A & N & E & G & \text { T } & A & 537\end{array}$

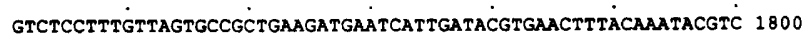

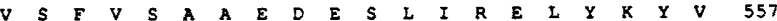

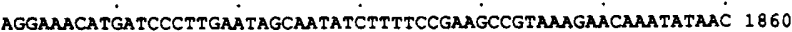
$\begin{array}{lllllllllllllllllllll}R & \text { K } & \text { H } & \text { D } & \text { P } & \text { L } & \text { N } & \text { S } & \text { N } & \text { I } & \text { F } & \text { S } & \text { E } & \text { A } & \text { V } & \text { K } & \text { N } & \text { K } & \text { Y } & \text { N } & 577\end{array}$ GTCGGCAAACAGCTCAGTAMTGAGATTATATATTAAAGTTATATTATTTTCTTTCTTTTT 1920 $V G \quad K Q I S S N E$ I I Y *

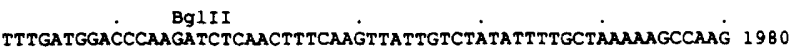
ACGCAAATTTACAAACTICATTGTCATTGAAAGTCGGGCTAACTACTTGTAGGCCTATTG 2040 GAAACCCATCTATCTCACCAGATTGTATTAAATCATTCCAATATGTTTTGATCATTTTAT 2100 CTTCTGGATTGAGCGCAGAAGTGGTATCCATTAGCCCATCAATTIGGCAATCGACACTAC 2160

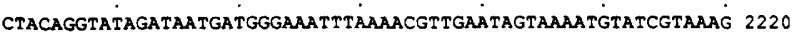
TTGTCTTTAGCATGTCACCAGGCCTAAATGGCATCAGCGTTGTAGgagatatgataACAT 2280 CAGGCCTtTCTGATTCCGGGAAAGAAAGGTAATAATCTCTCATTAATTGTTGTGCATTAT 2340 AAACTCTTTTGGTCAAATCCCACCATTCATTAACAGTATATGGGGGCCTTCCGTTTTCCA 2400

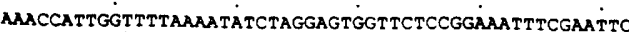
2452

Figure 4. Nucleotide and predicted protein sequence of $2.5-\mathrm{kb}$ complementing fragment. The prp28-1 mutation is shown above nucleotide $1019\left({ }^{*} \mathrm{~A}^{*}\right)$, and the predicted amino acid change is shown below amino acid $297\left({ }^{\star} \mathrm{E}^{\star}\right)$. Restriction sites referred to in the text are indicated.

mants were viable at the nonpermissive temperature. PRP28 therefore defines a new complementation group.

\section{PRP28 encodes a putative ATP-dependent helicase}

We cloned the wild-type $P R P 28$ gene by complementing the cold sensitivity with yeast genomic DNA plasmid libraries and obtained three plasmid-dependent cold-insensitive survivors, one from a low-copy-number CEN bank (Burgess et al. 1990) and two from a high-copynumber $2 \mu$ bank (Carlson and Botstein 1982). All three clones contained the same complementing piece of DNA (data not shown). Subsequent analysis was carried out with the CEN plasmid.

We identified a 2.5-kb EcoRI fragment capable of complementing prp28-1 cold sensitivity. Sequence analysis (Fig. 4) revealed an open reading frame of 588 amino acids, encoding a protein with a predicted molecular mass of $67 \mathrm{kD}$. PRP28 contains a 300-amino-acid domain with motifs shared by a family of proteins that are thought to function as ATP-dependent RNA helicases (Fig. 5). Though many sequence elements in this class of proteins are conserved from Escherichia coli to mammals, the precise function of most is unknown. The crystal structures of several ATP- and GTP-binding proteins show that the conserved G/AX $\mathrm{AXKT}_{4}$ motif, characteristic of NTP-binding proteins, forms a turn between a $\beta$ strand and an $\alpha$-helix (de Vos et al. 1988; Drevsicke et al. 1988; Pai et al. 1989|. This alternating structure, first proposed by Rossmann et al. (1974) as a core component of a canonical "dinucleotide fold" appears to bind the $\beta / \gamma$ phosphates of the NTP molecule.

PRP28 contains all of the signature sequences of the ATP-dependent RNA helicase gene family, as seen in Figure 5. With the exception of eIF4A, which is thought to unravel mRNA secondary structure during translation initiation (Rozen et al. 1990), little is known about the specific biological function of these proteins. Notably, however, this family includes two other proteins involved in RNA splicing, MSS116 and PRP5 (Seraphin et al. 1989; Dalbadie-McFarland and Abelson 1990). Two other members, $S R M B$ and $S P B 4$, function in ribosome 


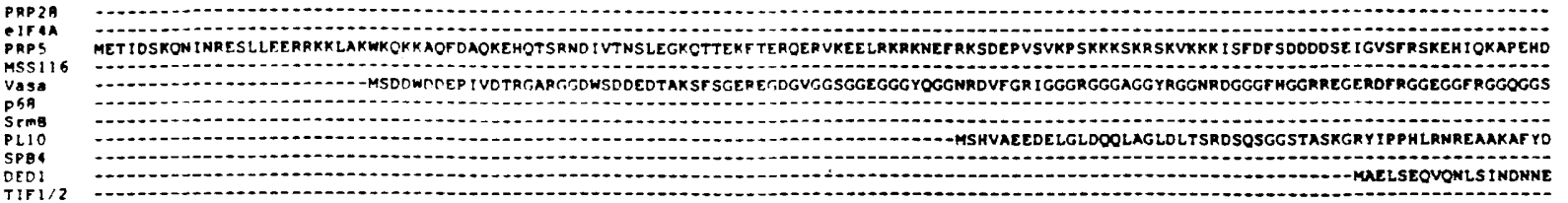

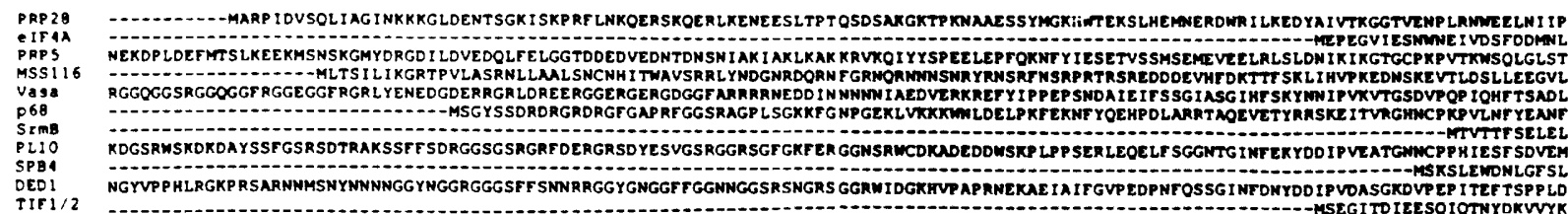

PRP 28 RD LLRVI IOELREPSPTP IORITI PNVCNAKOYRDFLGVASTGSGKTLAFVIP ILIKMSRSPP RPPSLKIIDG EIFA SESLLRGI YAYGEEKPSAIOORAIL P CI K G YDVUAOAOSGTGKAATFAISILOLIELDLKA

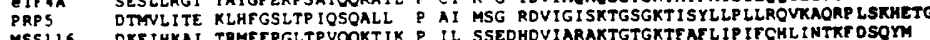

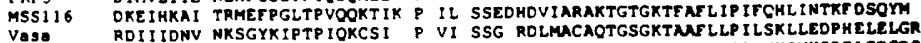

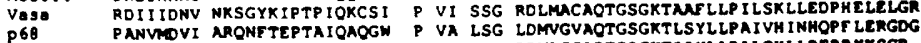

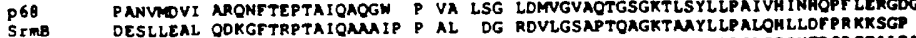

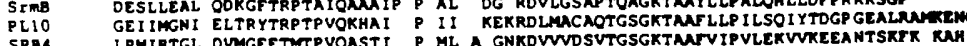

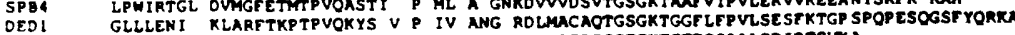
TIFI/2 FODMLLOENLLRGVGGGGEEP SA IQORA IMP I IEGHDVLAOAOSGTGKTGTSSIMLOR IOTSVKA

consensus

G DV A AOTGSGKT F P L

PRALILAPTRELVOQTOKETOHVTKIWSKESWYO CKVISIVGGHSL TOALVLAPTRELAOOTOKWMULGO NAGASCHA CI GGTN

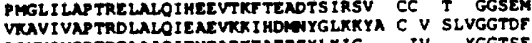
POVWIVSPTRELAIOIFMENUKF NESYLKIG IV YGGTSE PICLVLNPTRELAOQVOOVMMEYCRACRLIST CI YGGAPR

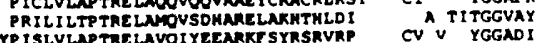

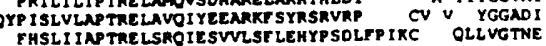

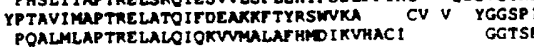

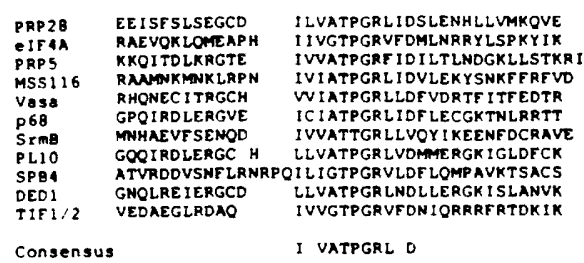

TLVLDEADKMIDLGFEDOVTNI LTKVDINADSAVNRO TLMFTATMTPVIEKIMAGYMOKPVYATIGVETGSEPL

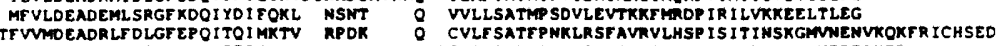

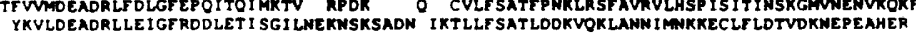
FWULDEADRMLDMGT SEDPAR I ITHYUTMRPEH O TLAT SATFPEE IORMAGEF LKNYVTVA IGIVGGACSD YLVDDEADRMLOMGEP OIRK I VDOI APOR O TLMWSATWPKEVROLAEOF LKOY IH INIGALCLSANHM TLILOEADRMLOHGF AOD IEHI AGETRMR $k$ O TLLFSATLECOA OOFAERLLEDPVEVSANP STRERKK

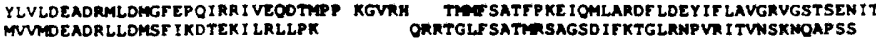

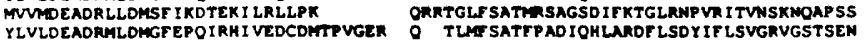

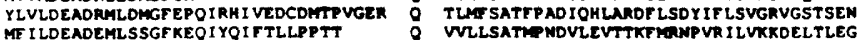
VLDEADRMLO Gr OI I Q I TSAT P
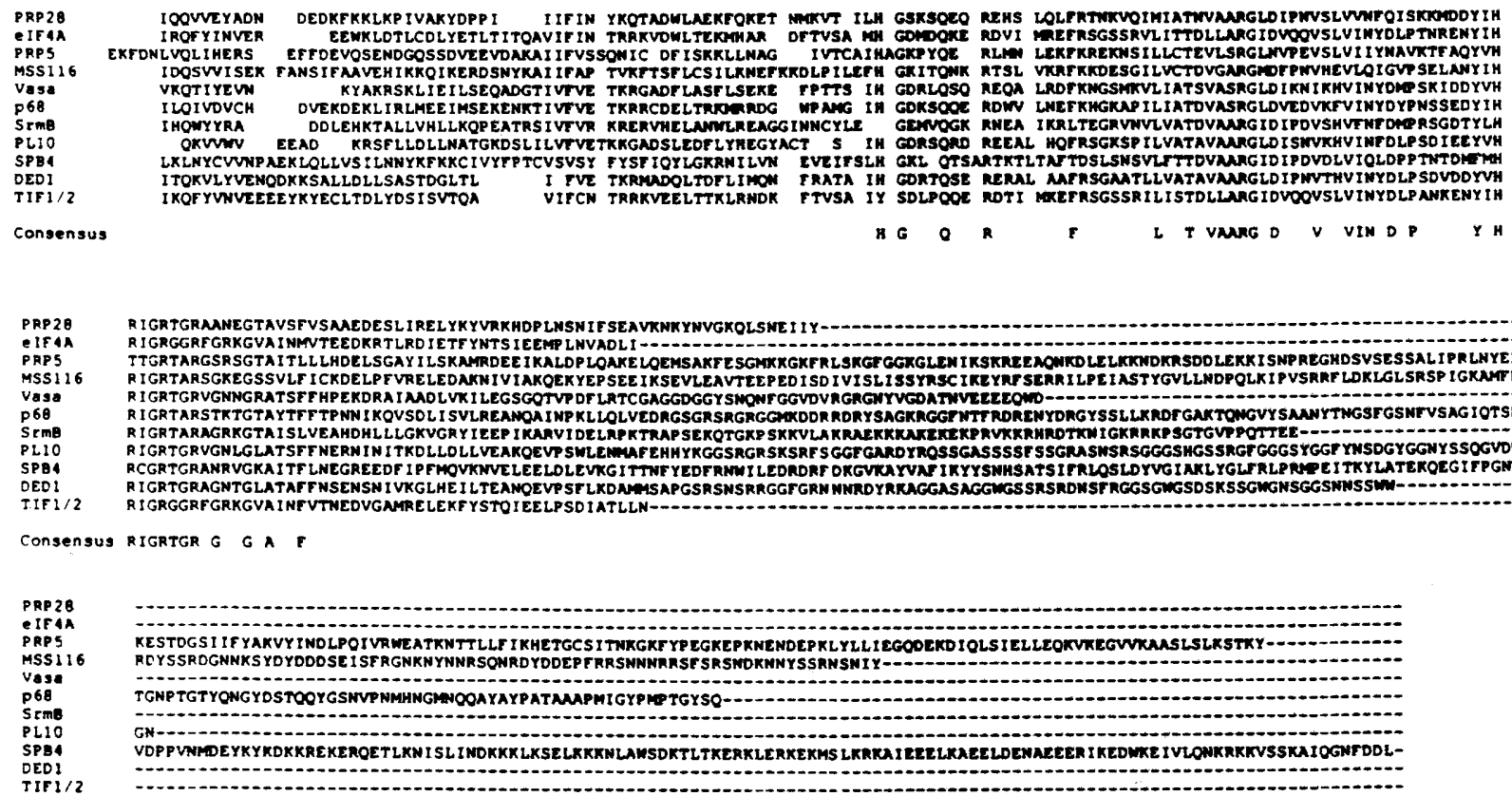

Figure 5. Alignment of DEAD-box proteins. Conserved motifs are indicated in Consensus. The putative NTP-binding site begins with the first $A$ in the third block of sequence and ends with the T of GKT. The DEAD box, which gives this family of proteins their name, appears near the middle of the fourth block of sequence. The site of the prp28-1 mutation is marked by an asterisk (*). (eIF4A) Nielsen et al. (1985); (PRP5) Dalbadie-McFarland and Abelson (1990); (MSS116) Seraphin et al. (1989); (Vasa) Hay et al. (1988); (p68) R. Iggo (pers. comm.); see also Hloch et al. (1990); (SrmB) Nishi et al. (1988, 1989); (PL10) Leroy et al. (1989); (SPB4) Sachs and Davis (1990); (DED1) B. Rahe and J. Pringle (pers. comm.); (TIF1/2) Linder and Slonimski (1989). 
assembly (Nishi et al. 1988, 1989; Sachs and Davis 1990). Five genes have been isolated in a direct screen for this class of proteins using polymerase chain reaction (PCR) technology, one of which is identical to PRP28 (Chang et al. 1990).

\section{PRP28 is essential}

To test whether PRP28 is an essential gene, we made a null allele in which all but 38 amino acids of $P R P 28$ are replaced with TRP1. We transformed a diploid strain and selected for $\operatorname{Trp}^{+}$transformants. Insertion at the PRP28 locus was confirmed by Southern analysis (data not shown). Tetrads from this strain yielded only two viable spores, and none of these were Trp auxotrophs. We therefore conclude that $P R P 28$ is an essential gene.

We mapped the $5^{\prime}$ end of the PRP28 message using primer extension and $S 1$ nuclease protection analysis. There are three transcription initiation sites, all beginning within 27-34 nucleotides upstream of the first AUG (data not shown). These are used with approximately equivalent efficiencies. We therefore assume that the $5^{\prime}$-most AUG is the start codon.

\section{Cold sensitivity results from a single amino acid change in a conserved domain}

To identify the mutation responsible for the cold-sensitive growth and splicing defect, we used the method of gap repair (Orr-Weaver et al. 1981). Plasmids bearing the wild-type gene were linearized with either SacI or $E c o \mathrm{RV}$, which each cut once in the coding region of the gene. These linearized plasmids were then used to transform a haploid cs 1 strain, and $\mathrm{Ura}^{+}$transformants were selected. To remain stably in the cell, the plasmid must be repaired using the chromosomal copy of the gene as a template (Orr-Weaver et al. 1981, 1988). At a frequency dependent on the distance between the cut and the mutation, the plasmid will be "repaired" to the mutant sequence. These cells will be cold-sensitive, because they now contain two copies of the mutated gene. Fifty $\mathrm{Ura}^{+}$ transformants from each transformation were streaked on $\mathrm{Ura}^{-}$plates and incubated at $18^{\circ} \mathrm{C}$. Six cold-sensitive isolates were identified, four from the SacI- and two from the EcoRV-digested DNA. Plasmids were isolated and partially sequenced.

A G-to-A mutation at position 1019 was identified that results in replacement of a conserved glycine with a glutamic acid (Figs. 4 and 5). To demonstrate that this mutation is necessary and sufficient for cold-sensitive growth, we exchanged a 223-nucleotide restriction fragment (BstEII-MscI; see Fig. 4 and legend to Fig. 6) containing the mutation with the same fragment from the wild-type clone. As shown in Figure 6, these cells are cold-sensitive.

\section{prp28, prp24 double mutants are inviable}

As a first step in determining the specific function of PRP28, we have employed genetics to identify factors with which the protein may interact. Of particular interest is the substrate for the putative helicase activity; one obvious candidate is the U4/U6 complex. To investigate this possibility, we first tested whether prp28-1 strains are hypersensitive to mutations in U4- or U6associated proteins.

PRP24 is a protein identified genetically by mutations that suppress the cold-sensitive phenotype of the U4G14C mutation. Antibodies to PRP24 coimmunoprecipitate U6 snRNA in wild-type strains, and $\mathrm{U} 4$ as well as U6 in U4-G14C strains (Shannon and Guthrie 1991). Tetrads from a diploid heterozygous for both the temperature-sensitive allele prp24-1 (for summary of growth phenotypes of strains discussed in this paper, see Table 1A) and prp28-1 were dissected and incubated at $25^{\circ} \mathrm{C}$, a temperature permissive for each single mutant (see Table 1A). Two noninteracting, unlinked mutations are expected to generate equal numbers of each phenotypic class: wild type, cold sensitive, temperature sensitive, and cold sensitive/temperature sensitive. However, we recovered only one (extremely sick) cold-sensitive/temperature-sensitive double mutant (prp24-1, prp28-1) of

Figure 6. Growth phenotypes of csl containing wild-type and mutant plasmids. (Left) $30^{\circ} \mathrm{C}$; (Right) $18^{\circ} \mathrm{C}$. (WT) Wild-type PRP28 clone (pHD20); (gap repair) original gap-repaired clone (Sac7); (WT swap) 223-nucleotide restriction fragment (BstEII-MscI) of pHD20 cloned into the same sites of Sac7; (gap repair swap) 223nucleotide restriction fragment (BstEII-MscI) of Sac7 /containing G-to-A mutation at position 1019) cloned into the same sites of pHD20.

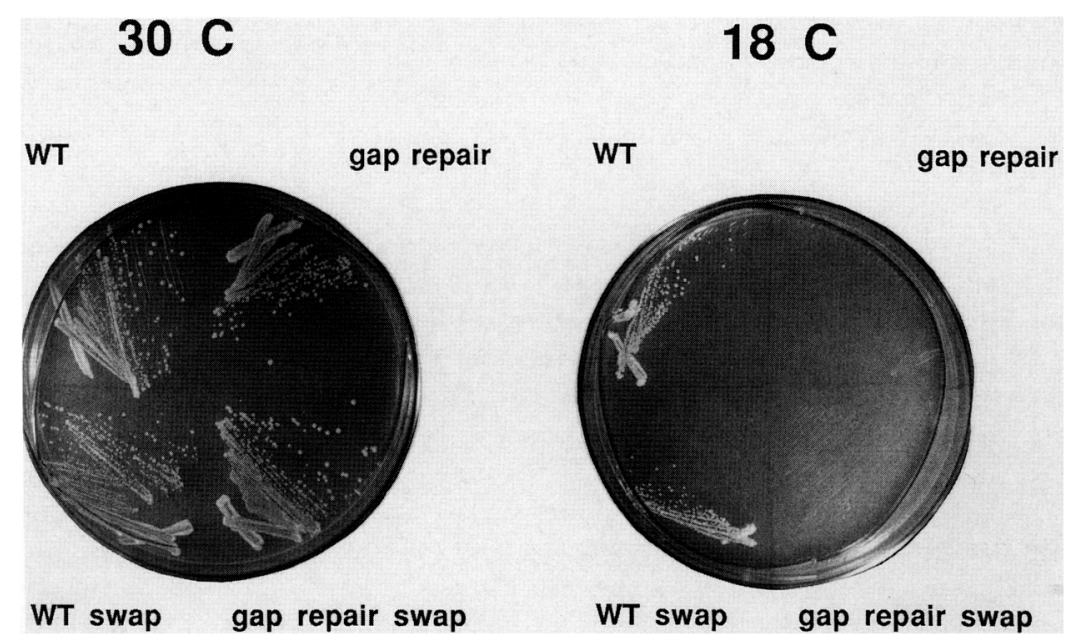


Table 1. Growth phenotypes and tetrad dissection data

\begin{tabular}{|c|c|c|c|c|}
\hline \multicolumn{5}{|c|}{ A. Growth phenotypes of strains } \\
\hline \multicolumn{2}{|l|}{ Genotype } & 18 & 25 & 37 \\
\hline \multicolumn{2}{|l|}{ prp28-1 } & - & + & + \\
\hline \multicolumn{2}{|l|}{ prp24-1 } & + & + & - \\
\hline \multicolumn{2}{|l|}{ prp5-1 } & + & + & - \\
\hline \multicolumn{2}{|l|}{ spp281-1 } & + & + & - \\
\hline \multicolumn{2}{|l|}{ prp8-1 } & + & + & - \\
\hline \multicolumn{2}{|l|}{ prp28-1/PRP28 } & + & + & + \\
\hline \multicolumn{2}{|l|}{ prp24-1/PRP24 } & + & + & + \\
\hline \multicolumn{2}{|l|}{ spp281-1/SPP281 } & + & + & + \\
\hline \multicolumn{2}{|l|}{ prp8-1/PRP8 } & + & + & + \\
\hline \multicolumn{2}{|l|}{ prp24-1, prp28-1 } & NA & - & NA \\
\hline \multicolumn{2}{|l|}{ prp5-1, prp24-1 } & + & + & - \\
\hline \multicolumn{2}{|l|}{ prp5-1, prp28-1 } & - & + & - \\
\hline & - & + & - \\
\hline \multicolumn{2}{|l|}{$\begin{array}{l}\text { prp28-1/prp28-1, } \\
\text { spp281-1/SPP281 }\end{array}$} & $+1-$ & + & + \\
\hline \multicolumn{5}{|c|}{ B. Tetrad dissection data } \\
\hline & \multicolumn{4}{|c|}{$\begin{array}{l}\text { Genetic crosses } \\
\text { (no. of spores) }\end{array}$} \\
\hline & $\operatorname{cs}^{+}, \mathrm{ts}^{+}$ & $\mathrm{cs}, \mathrm{ts}^{+}$ & $\mathrm{cs}^{+}, \mathrm{ts}$ & $\mathrm{cs}, \mathrm{ts}$ \\
\hline prp28-1 × prp2-1 & 5 & 8 & 7 & 7 \\
\hline prp $28-1 \times$ prp3-1 & 5 & 13 & 9 & 8 \\
\hline prp $28-1 \times$ prp $4-1$ & 6 & 7 & 10 & 7 \\
\hline prp $28-1 \times$ prp $5-1$ & 6 & 4 & 9 & 3 \\
\hline prp 28-1 × prp6-1 & 13 & 11 & 9 & 14 \\
\hline prp $28-1 \times$ prp $7-1$ & 9 & 7 & 6 & 15 \\
\hline prp $28-1 \times$ prp $8-1$ & 28 & 27 & 24 & 21 \\
\hline prp28-1 × prp11-1 & 2 & 7 & 10 & 6 \\
\hline prp $28-1 \times$ prp $24-1$ & 29 & 29 & 31 & 1 (sick) \\
\hline \multicolumn{5}{|l|}{ prp28-1spp281-1 $\times$} \\
\hline \multirow[t]{4}{*}{ prp28-1SPP281 } & 0 & 19 & 21 & 0 \\
\hline & PRP5, & prp5-1, & PRP5, & prp5-1, \\
\hline & PRP24 & PRP24 & prp24-1 & prp24-1 \\
\hline & $\left(\mathrm{ts}^{+}\right)$ & $\mathrm{ts}^{\mathrm{a}}$ & $\mathrm{ts}^{\mathrm{a}}$ & $\mathrm{ts}^{\mathrm{a}}$ \\
\hline \multicolumn{5}{|l|}{ prp5-1 $\times$} \\
\hline prp24-1 & 7 & 9 & 13 & 13 \\
\hline
\end{tabular}

(NA) Not applicable.

${ }^{a}$ The genotypes of temperature-sensitive $(\mathrm{ts})$ spores from this cross were determined by carrying out complementation tests with prp5-1 and prp24-1 strains of appropriate mating types. Spores complementable by prp5-1 were scored as PRP5, prp241 ; those complementable by prp24-1 were scored as prp51, PRP24; and those not complementable by either were scored as prp5-1, prp24-1.

90 viable spores (for summary of tetrad dissection data, see Table 1B). Frequencies for the other classes of spores were as expected: Twenty-nine were completely wildtype (PRP24, PRP28), 29 were cold-sensitive (PRP24, prp28-1), and 31 were temperature-sensitive (prp24-1, PRP28). We conclude that cells cannot tolerate both mutations simultaneously. This phenomenon has been termed synthetic lethality (Dobzhansky 1946). (The double mutant recovered presumably contains a third mutation, which suppresses the lethal phenotype.) It is un- likely that the synthetic lethality is due to a nonspecific additive effect of the two mutants because it is specific to this pair of splicing mutants; haploid cells containing prp28-1 in combination with prp2-prp8 and prp11 are viable (see Table 1B).

Because PRP5 also encodes a putative RNA helicase involved in splicing, it was of interest to determine whether (1) the synthetically lethal interaction with prp24-1 is specific to prp28-1, and (2) the helicases might carry out overlapping functions, in which case prp28-1 cells might be hypersensitive to mutations in PRP5. We therefore analyzed progeny from prp5-1, prp28-1, and prp5-1, prp24-1 crosses. In both cases, viable double mutant spores were obtained (Table 1B). The simplest interpretation of these results is that PRP28 and PRP5 normally play functionally distinct roles.

\section{A suppressor of prp28 is prp8}

A standard method for identifying genetically interacting gene products is to seek second site suppressors. Of particular interest are suppressors that also exhibit an independent phenotype, because this greatly facilitates the assignment of complementatinn groups and assessment of the phenotype of the su' ssor locus. Ten independent cultures of prp28-1 $\mathrm{c} \quad$ re grown to saturation at $30^{\circ} \mathrm{C}$, and $10^{7}$ cells ${ }^{s}$ were plated on YPD. These plates were inc $\quad 8^{\circ} \mathrm{C}$, and eight colonies from each plate wr 'purified. The revertants were then scree $y$ to grow at $37^{\circ} \mathrm{C}$. We obtained five inc rature-sensitive suppressors of prp2\& e (spp281-1) proved to be particularly suppression phenotype of spp281-1 is 1 the temperature-sensitive phenotype a. ingle gene: In a backcross between the a (containing prp28-1 and spp281-1) and ee- and fourspored tetrads were obtaine $\quad 40$ spores, 21 were temperature-sensitive, ese were coldinsensitive (Table 1B). spp281 2rs temperature sensitivity in a wild-type $P R L_{\text {a }} \quad$. The suppressor function is semidominant becau loids homozygous for prp28-1 and heterozygous for he suppressor grow nearly as well as the original hapl id revertant at $18^{\circ} \mathrm{C}$. The spp281-1 mutation does not reside in the PRP28 gene because a plasmid bearing he wild-type $P R P 28$ gene cannot rescue the recessive 1 emperature-sensitive growth defect.

To determine whether the five 1 emperature-sensitive suppressors correspond to known splicing factors, we carried out complementation test $s$ with the temperature-sensitive strains prp2-prp1C', prp17-prp24, and prp27. The spp281-1 strain failed to complement the temperature-sensitive defect of a prp8-1 strain, though diploids from the other crosses grew at $37^{\circ} \mathrm{C}$, demonstrating that the temperature-sensitive phenotype of spp281-1 is recessive. We investigated whether the wildtype $P R P 8$ gene could rescue the temperature-sensitive defect conferred by spp281-1. spp281-1 cells were transformed with a low-copy plasmid bearing $P R P 8$ or with 
the vector alone. Transformants containing PRP8 were able to grow at $37^{\circ} \mathrm{C}$, indicating that $\operatorname{spp} 281-1$ is a mutant allele of PRP8. We have thus renamed the suppressor locus prp8-9. Interestingly, PRP8 is a known U5 protein (Lossky et al. 1987). The prp8-9 allele thus appears to identify a genetic interaction between $P R P 28$ and the U5 snRNP.

\section{Discussion}

PRP28 defines a new splicing factor

We have isolated a cold-sensitive splicing mutant that defines a complementation group distinct from those of previously identified temperature-sensitive splicing mutants. Strains harboring this mutation accumulate premRNA after a shift to the nonpermissive temperature. The growth and splicing defects of the mutant cosegregate, defining a single allele, prp28-1. The lethal phenotype of a null allele (prp28::TRP1) demonstrates that as for all other genes encoding splicing factors that have been analyzed to date, the PRP28 gene product is essential for growth.

The prp28-1 mutation lies in a motif highly conserved among members of the ATP-dependent RNA helicase gene family

We cloned the wild-type PRP28 gene by complementing the cold-sensitive phenotype with a wild-type, singlecopy yeast bank (construction described in Burgess et al. 1990). Sequence analysis of the smallest complementing fragment revealed a single open reading frame of 588 amino acids, which should encode a protein with a predicted molecular mass of $67 \mathrm{kD}$. As shown in Figure 5, this sequence contains matches to seven of the seven motifs common to a family of 10 proteins believed to function as ATP-dependent RNA helicases / the "DEADbox" family, named after this conserved tetrapeptide) (Linder et al. 1989), on the basis of the in vitro activities of two of its members, p68 and eIF4A (Hirling et al. 1989; Rozen et al. 1990). With the exception of eIF4A, which is thought to unwind secondary structure in mRNA during translation initiation, the biological functions of the genes in this family are unknown.

The mutation responsible for the cold sensitivity in prp28-1 was isolated and found to be a single nucleotide change at position 1019 (G to A), which results in conversion of a highly conserved glycine to glutamic acid (see Fig. 5). This is one of two adjacent glycines that appears in all members of this family except $S P B 4, \sim 20$ amino acids downstream from the PTREL and 40 amino acids upstream from the VLDEAD sequences. The presence of this residue in all of these proteins implies a conserved function.

\section{PRP28 displays genetic interactions with the U4/U6 and U5 snRNPS}

The most obvious candidate substrate for an RNA helicase involved in splicing is the U4/U6 snRNP. As de- tailed in the introductory section, disruption of this extensively base-paired particle prior to the first nucleolytic cleavage is the most striking conformational change known in the splicing pathway.

We used a genetic approach to identify interactions between PRP28 and genes implicated in U4/U6 function. prp28-1 and prp24-1 mutations are synthetically lethal: Haploid cells containing both of these mutations are inviable under conditions in which each single mutant is viable. This observation is interesting because several mutant alleles of PRP24 were isolated as suppressors of a U4 mutation, and PRP24 has been shown to be a U6associated protein (Shannon and Guthrie 1991). These results are consistent with the hypothesis that the PRP28 and PRP24 gene products functionally associate during splicing, perhaps during the unwinding of the U4/ U6 snRNP. Synthetic lethal interactions have been identified for alleles of a number of proteins that are known to interact physically: actin and the SAC6 gene product (Adams and Botstein 1989; Adams et al. 1989), $\alpha$ - and $\beta$-tubulin (T. Stearns, pers. comm.), and SEC61p, SEC62p, and SEC63p (Rothblatt et al. 1989; R. Deshaies, pers. comm.).

We identified a second genetic interaction by isolating a suppressor of prp28-1, spp281-1, which has a temperature-sensitive phenotype on its own. Intriguingly, the temperature-sensitive growth phenotype conferred by spp281-1 fails to complement that of prp8-1. The wildtype PRP8 gene (supplied on a low-copy plasmid) alleviates the temperature sensitivity in a spp281-1 strain. Therefore, spp281-1 defines an allele of PRP8, prp8-9.

\section{A model for PRP28 function}

Until biochemical data are available, the precise role of PRP28 in splicing cannot be known. However, the genetic interactions we have identified are consistent with a simple model for PRP28 function as a helicase that unwinds U4 and U6 in the context of the U4/U6/U5 snRNP in the spliceosome; this is diagramed in Figure 7. In this model PRP24 protein facilitates the unwinding of U4/U6 by binding to and thus stabilizing the unwound form of U6. PRP24 contains three regions homologous to the RNP consensus domain conserved among many RNA-binding proteins and has been shown to bind tightly to U6 snRNA by immunoprecipitation studies (Shannon and Guthrie 1991). The substrate U4/U6 in this scenario is associated with a U5 particle containing the PRP8 protein, which would act to stabilize the basepaired form. The synthetic lethality and suppression results could then be explained by recessive, loss-of-function mutations in PRP24, PRP28, and PRP8. The dominant suppression of the prp28-1 cold-sensitive phenotype by prp $8-9$ would be due to the ability of the U5 particle containing the spp281-1 product to assemble into the spliceosome. Once there, it would augment the diminished helicase activity of prp28-1 by stabilizing the tightly associated form of U4/U6 less well than its wildtype counterpart would, making the RNA duplex easier to unwind. 


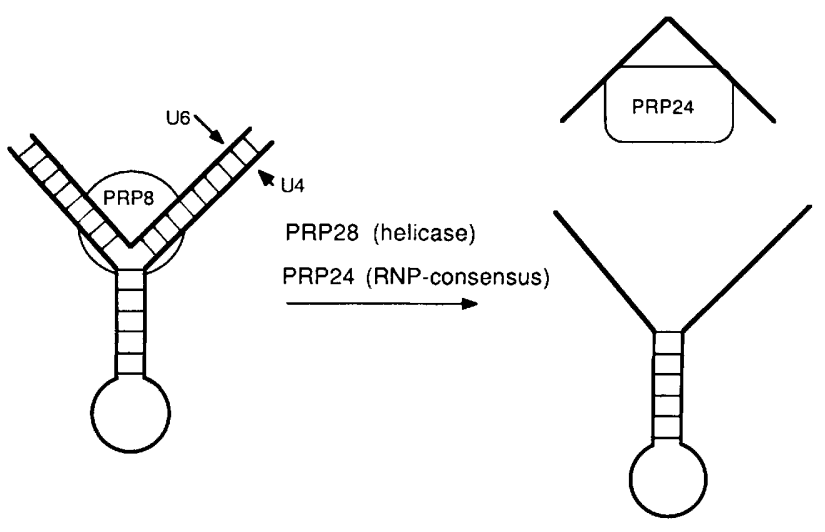

Figure 7. Model for PRP28 activity. PRP28 is proposed to unwind the U4/U6 helix. PRP8 would stabilize the base-paired form of U4/U6 snRNP, and PRP24 would stabilize the unwound form. Decreased activity of PRP8 would favor the right-hand side of the equation, and decreased activity of PRP24 would favor the left-hand side.

Obviously, other possibilities for PRP28 function exist; there are also other putative helicases implicated in splicing that could unwind the U4/U6 snRNP /see below). We present this model because the genetic results are consistent with a role for PRP28 in the event in splicing that most obviously points to the requirement for RNA helicase activity. Experiments to test the biochemical predictions of this model are under way.

\section{Seven putative ATPases are implicated in nuclear mRNA splicing}

PRP5, a protein required for mRNA splicing in vivo and in vitro, also contains all of the motifs characteristic of the eIF4A family (see Fig. 5; Dalbadie-McFarland and Abelson 1990). Interestingly, genes for two additional DEAD-box proteins that have been implicated in mRNA splicing interact genetically with U5. SPP81 (also called $D E D 1$ ) is a cold-sensitive suppressor of a temperaturesensitive allele of the U5 protein, prp8-1, and DBP1 was identified as a suppressor of the cold sensitivity of SPP81; each contains the consensus sequences shown in Figure 5 (D. Jamieson and J. Beggs, pers. comm.).

Interestingly, the four DEAD-box proteins implicated in splicing constitute only one of two classes of putative ATPases involved in this process. The second class of proteins (PRP2, PRP16, PRP22) contain sequence motifs that are clearly related to the DEAD-box family; however, there are significant variations (e.g., DEAH vs. DEAD) (Burgess et al. 1990; Chen and Lin 1990; Company et al. 1991).

As described in the introductory section, the splicing pathway requires ATP at many steps. This probably reflects various uses for ATP hydrolysis. It has been suggested that PRP16 plays a role in maintaining fidelity by coupling ATP binding and/or hydrolysis to accurate branchpoint recognition (Burgess et al. 1990). Another possible role for ATP hydrolysis is as an energy source to drive the reaction forward through a very precise path- way; it is inviting to speculate that each of the putative ATPases uses ATP hydrolysis to drive conformational changes that sequentially modify RNA/protein interactions in the assembling and disassembling spliceosome.

\section{Materials and methods}

Yeast media were prepared as described by Rose et al. (1989). AMV reverse transcriptase was obtained from Life Sciences. S1 nuclease was obtained from Boehringer Mannheim. Restriction enzymes were obtained from New England Biolabs, BRL, Boehringer Mannheim, and U.S. Biochemicals. T4 polynucleotide kinase was obtained from U.S. Biochemicals. dATP labeled with ${ }^{32} \mathrm{P}$ was obtained from Amersham, and $\left.{ }^{32} \mathrm{P}\right] \mathrm{ATP}$ was obtained from ICN. Oligonucleotides were synthesized by the Biomolecular Resource Center at University of California, San Francisco.

\section{Oligonucleotides}

The following oligonucleotides were employed in this work:

CHY2 exon 2
RP73 exon 2
MATa1 exon 3
cs1-5' end
cs1-seq
Sac-mer
RV-mer
Rsa-mer
$2150 \mathrm{~A}$
$2150 \mathrm{C}$
$900 \mathrm{~A}$
$900 \mathrm{~T}$
370
1360
T3 primer
T7 primer

5'-TGCTTACCGATACGACCTTTA - $3^{\prime}$ 5'-TTTGGTTGATAGATTCTTGGG-3'

$5^{\prime}$-GAATTTATTTAGATCTCATACGTTT- $3^{\prime}$ 5'-TCTTGTTTATACCAGCAATCAGC-3' 5'-GTCAATTAAACGTCCTGGAGT-3' 5'-GAGAGAGATTGGAGGATACTA-3' 5'-GGGAACATTCTTTGCAATTATT T-3' 5'-GTGACATCCTGGTGGCCAC-3' 5'-GGCAATCGACACTACCTACA-3' $5^{\prime}$-CGATTGCCAAATTGATGGGC- $3^{\prime}$ 5'-AGCGTTAATTTTAGCTCCAACA-3' 5'-CGCTTTGGGGCCATCAATAAT-3' 5' -TTCAATGAAACAAATGATAAGAAGA- ${ }^{\prime}$ 5'-CGGGT TCTGAACCTTTGATTC-3' 5'-ATTAACCCTCACTAAAG-3' 5'-AATACGACTCACTATAG-3'

Strains

The following strains were employed in this work:

YJC13, the parent strain used for mutagenesis: MATa, ura3, his4, trp1, leu2

TR3, the wild-type strain used for outcrossing lobtained from Phil Hieter): MAT $\alpha$ ura3 lys2 his3 ade2 trp1

YBP67: $\quad$ MAT $\quad$ prp2 ura3-52 leu2 his ade tyr1

RL92: $\quad$ MATa prp2 ura3-52 leu2-3 leu2-112

ma3-1-3A: $\quad$ MATa prp3 leu ade

SPJ3.33: $\quad$ MATa prp3 ura3-52 leu2 lys2 his3

YBP69: $\quad$ MATa prp4 ura3-52 leu2 lys2 his7 ade

YBP70: $\quad$ MAT $\quad$ prp4 ura3-52 leu2 lys2 ade

rna4-1: $\quad$ MATa prp4 ura1 lys2 his7 ade1 ade2 tyr1 gal1

YBP71: $\quad$ MATa prp5 ura3-52 leu2 his7

YBP72: $\quad$ MAT 2 prp6 ura3-52 lys2 his3

rna6-1: $\quad$ MATa prp6 ura1 lys2 his7 ade1 ade2 tyr1 gal1

YBP73: $\quad$ MAT $\alpha$ prp7 leu2 lys2 his

rna8 (AH): $\quad$ MAT $\alpha$ prp8 ura1 ade arg trp

ma8-1: $\quad$ MATa prp8 ura1 lys2 his7 ade1 ade2 tyr1

YBP80: $\quad$ MATa prp8 lys2 his3 ade2 trp1

SPJ10.2: $\quad$ MAT $\quad$ prp11 ura leu lys his ade tyr

YBP74: $\quad$ MATa prp11 ura3-52 leu2 his4-512

YDL15: $\quad$ MATa ura3-52 prp16 leu2 lys2 his3 ade2 trp1 prp17-prp27 strains were the kind gift of Usha Vijayraghavan, Mahshid Company, and John Abelson.

YJC52, used to construct the gene replacement was the kind gift of John Chant: MATa/MATa, trp1/trp1, ura3-52/ura3-52, his4/ his4. 


\section{Genetic methods}

All genetic manipulations, including yeast transformations, were done as described by Rose et al. (1989).

\section{Mutagenesis}

YJC13 was grown to saturation, washed with water, and UVirradiated for 30 or $45 \mathrm{sec}$. (This treatment had been calibrated previously to give $0.4-4 \%$ survival with this strain.) Cells were plated and incubated at $25^{\circ} \mathrm{C}$. Survivors were tested for viability at $16^{\circ} \mathrm{C}$ and $37^{\circ} \mathrm{C}$.

\section{DNA libraries and isolation of PRP28 clones}

Two DNA libraries were used: The CEN bank was obtained from Joe Couto (Burgess et al. 1990), and the $2 \mu$ bank was obtained from Marian Carlson (Carlson and Botstein 1982). Subcloning was achieved by inserting restriction fragments into a $C E N, U R A 3$ yeast vector (pSE360) and testing for ability to complement the cold sensitivity conferred by prp28-1 (see Plasmids, below, pHD1, pHD4, pHD14, and pHD20).

\section{Plasmids}

Plasmids used for sequencing are as follows:

pBJ1: $\quad 3.2-\mathrm{kb}$ SacI fragment of pHD4 cloned into the SacI site of Bluescript.

pBJ2: $\quad 2.3-\mathrm{kb}$ SacI fragment of pHD4 cloned into the SacI site of Bluescript.

pBJ3-2: $\quad 2.5-\mathrm{kb}$ EcoRI fragment of pHDl4 cloned into the EcoRI site of Bluescript.

pBJ4: $\quad$ 530-bp PstI fragment of pBJ3-2 cloned into the PstI site of Bluescript.

pBJ5: $\quad 800-\mathrm{bp} E c o \mathrm{RV}$ fragment of $\mathrm{pBJ} 3-2$ cloned into the EcoRV site of Bluescript.

pBJ6: $\quad 950-b p$ EcoRV-SacI fragment of pBJ3-2 cloned into the EcoRV/SacI sites of Bluescript.

pBJ8: 450-bp RsaI-SacI fragment of pBJ3-2 cloned into the EcoRV/SacI sites of Bluescript.

pBJ9: $\quad 300-b p$ EcoRV-BqlII fragment of pBJ3-2 cloned into the EcoRV site of Bluescript.

pBJ10: $\quad 500-b p$ EcoRV-BglII fragment of pBJ3-2 cloned into the EcoRV site of Bluescript.

Plasmids used for gene replacement are as follows:

pPH336: $\quad$ pBR322 containing TRP1.

pBJ13-11: 2.5-kb EcoRI fragment of $\mathrm{pBJ} 3-2$ cloned into EcoRI site of pUC19.

pBJ16-5: TRP1 BglII fragment of pPH336 cloned into 3.4-kb BgIII fragment of $\mathrm{pBJ} 13-11$.

\section{Other plasmids}

pSE360 was constructed and provided by Steve Elledge (Elledge and Davis 1988). It contains the yeast $A R S 1, C E N 4, A m p^{r}$, $U R A 3$, and a polylinker region in E. coli lac $Z^{\prime}$.

pHD1: 14-kb complementing fragment in TRP1 CEN vector; original clone from CEN bank (Burgess et al. 1990).

pHD2: $\quad 10-\mathrm{kb}$ complementing fragment in URA3 $2 \mu$ vector; original clone from high copy $(2 \mu)$ bank (Carlson and Botstein 1982).
pHD3: $\quad 12-\mathrm{kb}$ complementing fragment in URA3 $2 \mu$ vector; original clone from high copy $(2 \mu)$ bank (Carlson and Botstein 1982).

pHD4: $\quad$ 7.5-kb BamHI-SmaI complementing fragment of pHDl cloned into SmaI site of pSE360.

pHD14: $\quad 5.5-\mathrm{kb}$ NaeI-SnaBI complementing fragment of pHD4 cloned into SmaI site of pSE360.

pHD20: $2.5-\mathrm{kb}$ fragment containing PRP28 cloned into EcoRI site of pSE360.

Sac7: One of the original gap-repaired plasmids obtained by digesting $\mathrm{pHD} 20$ with SacI prior to transformation (see Results).

Plasmids containing SNR19, SNR20, SNR14, SNR7, and SNR6 used in the complementation analysis are described in Siliciano et al. (1987a), Shuster and Guthrie (1988), Siliciano et al. (1987b), Patterson and Guthrie (1987), and Brow and Guthrie (1988), respectively.

pY8500, a plasmid containing PRP8 in yCP50 (Jackson et al. 1988), was provided by Jean Beggs.

\section{Primer extension and $S 1$ analysis}

RNA extraction was achieved by the method described in Vijayraghavan et al. (1989). Primer extensions were done according to Bensi et al. (1985). Methods to map the $5^{\prime}$ end of the PRP28 transcript were carried out on wild-type RNA. Oligonucleotides csl-seq and cs1-5' end were annealed for $20 \mathrm{~min}$ at $45^{\circ} \mathrm{C}$, and the oligonucleotide-RNA hybrid was ethanol-precipitated prior to the extension reactions. Ends were mapped by comparing mobilities of primer-extended products with those of DNA size markers or of a DNA sequencing reaction /using pBJ32 as a template), with end-labeled $\operatorname{csl}{ }^{-} 5^{\prime}$ end as a primer. $\mathrm{Sl}$ analysis was done according to Maniatis et al. (1982), using an empirically determined amount of S1 nuclease (5 units) on 20 $\mu \mathrm{g}$ of RNA. A double-stranded 833-nucleotide BstEII-BamHI DNA fragment was gel-purified by using Geneclean (Biol01) prior to end-labeling. Following this, the probe was incubated with RNA for $3 \mathrm{hr}$ at $50^{\circ} \mathrm{C}$.

\section{Sequencing and sequence analysis}

DNA sequencing was carried out using the dideoxy method (Sanger et al. 1977) with the Sequenase kit (U.S. Biochemicals). Fragments to be sequenced were cloned into Bluescript plasmids (Stratagene): These are listed as the $\mathrm{pBJ}$ series under plasmids. Sequences not covered by this method were sequenced by using oligonucleotides that anneal to sequenced regions.

\section{Construction of gene replacement}

The prp28::TRP1 allele was created by cloning the 2.5-kb EcoRI fragment containing PRP28 into the EcoRI site of pUC19 to generate $\mathrm{pBJ} 13-11$. This plasmid was then digested with $B g I I I$, and the 3.4-kb fragment containing pUC19 and the $5^{\prime}$ and $3^{\prime}$ ends of the complementing EcoRI fragment was gel-purified by using Geneclean (Biol01). A 1.7-kb BglII fragment of DNA containing the TRP1 gene was purified from pPH336 (using Geneclean) and cloned into the $3.4-\mathrm{kb}$ pUC19/PRP28 vector prepared as described above. Integration of this allele into the chromosome was achieved by cutting the plasmid (pBJ16-5) with EcoRI prior to transformation.

\section{Acknowledgments}

We thank Steve Elledge for the plasmid pSE360, Joachim Li for the plasmid pPH336, and John Chant for the strain YJC52. We 
gratefully acknowledge Richard Iggo, Tien-Hsien Chang, Mahshid Company, John Abelson, Derek Jamieson, Jean Beggs, Bryan Rahe, John Pringle, Jiann-Hwa Chen, and Ren-Jang Lin for communicating results prior to publication. We thank Lucita Esperas for superb technical assistance. We also thank Tim Stearns, Debbie Zimmerman, Virginia Visconti, Sean Burgess, Beate Schwer, and other members of the Guthrie laboratory for their comments on the manuscript. We especially appreciate the painstaking care and patience demonstrated by members of the Guthrie laboratory in putting Figure 5 together. This work was supported by National Institutes of Health (NIH) grant GM21119. E.S. was supported by NIH training grant 5 T32 CA09270 and Lucille P. Markey Charitable Trust predoctoral grant $84-12$

The publication costs of this article were defrayed in part by payment of page charges. This article must therefore be hereby marked "advertisement" in accordance with 18 USC section 1734 solely to indicate this fact.

\section{Note added in proof}

Sequence data described in this paper have been submitted to the EMBL/GenBank Data Libraries under accession number $\mathrm{X} 56934$.

\section{References}

Adams, A.E.M. and D. Botstein. 1989. Dominant suppressors of yeast actin mutations that are reciprocally suppressed. $G e$ netics 121: 675-683.

Adams, A.E.M., D. Botstein, and D.G. Drubin. 1989. A yeast actin-binding protein is encoded by $S A C 6$, a gene found by suppression of an actin mutation. Science 243: 231-233.

Banroques, J. and J. Abelson. 1989. PRP4: A protein of the yeast U4/U6 small nuclear ribonucleoprotein particle. Mol. Cell. Biol. 9: 3710-3719.

Bensi, G., G. Raugei, H. Klefenz, and R. Cortese. 1985. Structure and expression of the human haptaglobin locus. EMBO $J$. 4: 119-126.

Bindereif, A. and M.R. Green. 1987. An ordered pathway of snRNP binding during mammalian pre-mRNA splicing complex assembly. EMBO I. 6: 2415-2424.

Bordonné, R., J. Banroques, J. Abelson, and C. Guthrie. 1990. Domains of yeast U4 spliceosomal RNA required for PRP4 protein binding, snRNP-snRNP interactions, and pre-mRNA splicing in vivo. Genes ef Dev. 4: 1185-1196.

Bringmann, P., B. Appel, J. Rinke, R. Reuter, H. Theissen, and R. Lührmann. 1984. Evidence of the existence of snRNAs U4 and $\mathrm{U} 6$ in a single ribonucleoprotein complex and for their association by intermolecular base pairing. EMBO $J$. 3: $1357-1363$.

Brody, E. and J. Abelson. 1985. The "spliceosome": Yeast premessenger RNA associates with a $40 \mathrm{~S}$ complex in a splicingdependent reaction. Science 228: 963-967.

Brow, D. and C. Guthrie. 1988. Spliceosomal RNA U6 is remarkably conserved from yeast to mammals. Nature 334: 213-218.

Burgess, S., J.R. Couto, and C. Guthrie. 1990. A putative ATP binding protein influences the fidelity of branchpoint recognition in yeast splicing. Cell 60: 705-717.

Cantor, C.R. and P.R. Schimmel. 1980. Biophysical chemistry: The conformation of biological macromolecules pp. 287288. W.H. Freeman, San Francisco.

Carlson, M. and D. Botstein. 1982. Two differentially regulated mRNAs with different $5^{\prime}$ ends encode secreted and intracel- lular forms of yeast invertase. Cell 28: 145-154.

Chang, T.-H., J. Arenas, and J. Abelson. 1990. Identification of five putative yeast RNA helicase genes. Proc. Natl. Acad. Sci. 87: 1571-1575.

Chen, J.-H. and R.-J. Lin. 1990. The yeast PRP2 protein, a putative RNA-dependent ATPase, shares extensive sequence homology with two other pre-mRNA splicing factors. Nucleic Acids Res. 18: 6447.

Cheng, S.-C. and J. Abelson. 1987. Spliceosome assembly in yeast. Genes \& Dev. 1: 1014-1027.

Company, M., J. Arenas, and J. Abelson. 1991. Requirement of the RNA helicase-like protein PRP22 for release of messenger RNA from spliceosomes. Nature 349: 487-493.

Dalbadie-McFarland, G. and J. Abelson. 1990. PRP5: A helicaselike protein required for mRNA splicing in yeast. Proc. Natl. Acad. Sci. 87: 4236-4240.

de Vos, A.M., L. Tong, M. Milburn, P.D. Matias, J. Jancarik, S. Noguchi, S. Nishimura, K. Miura, E. Ohtsuka, and S.H. Kim. 1988. Three-dimensional structure of an oncogene protein: Catalytic domain of human c-H-ras p21. Science 239: 888893.

Dobzhansky, T. 1946. Genetics of natural populations. XIII. Recombination and variability in populations of Drosophila pseudoobscura. Genetics 31: 269-290.

Drevsicke, D., P.A. Karplus, and G. Schulz. 1988. Refined structure of porcine cytosolic adenylate kinase at $2.1 \mathrm{~A}$ resolution. J. Mol. Biol. 199: 359-371.

Elledge, S.J. and R.W. Davis. 1988. A family of versatile centromeric vectors designed for use in the sectoring-shuffle mutagenesis assay in Saccharomyces cerevisiae. Gene 70: 303312 .

Frendewey, D. and W. Keller. 1985. Stepwise assembly of premRNA splicing complexes requires U-snRNPs and specific intron sequences. Cell 42: 355-367.

Grabowski, P.J., S.R. Seiler, and P.A. Sharp. 1985. A multicomponent complex is involved in the splicing of messenger RNA precursors. Cell 42: 345-353.

Green, M.R. 1986. Pre-mRNA splicing. Annu. Rev. Genet. 20: $671-708$.

Guthrie, C. and B. Patterson. 1988. Spliceosomal snRNAs. Annu. Rev. Genet. 22: 387-419.

Guthrie, C., H. Nashimoto, and M. Nomura. 1969. Structure and function of Escherichia coli ribosomes VII. Cold-sensitive mutations defective in ribosome assembly. Proc. Natl. Acad. Sci. 63: 384-391.

Hartwell, L.H. 1967. Macromolecular synthesis in temperaturesensitive mutants in yeast. $J$. Bacteriol. 93: 1662-1670.

Hartwell, L.H., C. McLaughlin, and J. Warner. 1970. Identification of ten genes that control ribosome formation in yeast. Mol. Gen. Genet. 109: 42-56.

Hashimoto, C. and J.A. Steitz. 1984. U4 and U6 RNAs coexist in a single small ribonucleoprotein particle. Nucleic Acids Res. 12: 3283-3293.

Hay, B., L.Y. Jan, and Y.N. Jan. 1988. A protein component of Drosophila polar granules is encoded by vasa and has extensive sequence similarity to ATP-dependent helicases. Cell 55: $577-587$.

Hirling, H., M. Scheffner, T. Restle, and H. Stahl. 1989. RNA helicase activity associated with the human p68 protein. $\mathrm{Na}$ ture 339: 562-564.

Hloch, P., G. Schiedner, and H. Stahl. 1990. Complete cDNA sequence of the human p68 protein. Nucleic Acids Res. 18: 3045 .

Huffaker, T.C., J.H. Thomas, and D. Botstein. 1988. Diverse effects of $\beta$-tubulin mutations on microtubule formation and function. J. Cell. Biol. 106: 1997-2010. 
Jackson, S.P., M. Lossky, and J.D. Beggs. 1988. Cloning of the RNA8 gene of Saccharomyces cerevisiae, detection of the RNA8 protein, and demonstration that it is essential for nuclear pre-mRNA splicing. Mol. Cell. Biol. 8: 1067-1075.

Jarvik, J. and D. Botstein. 1975. Conditional-lethal mutations that suppress genetic defects in morphogenesis by altering structural proteins. Proc. Natl. Acad. Sci. 72: 2738-2742.

Konarska, M.M. and P.A. Sharp. 1987. Interactions between small nuclear ribonucleoprotein particles in formation of spliceosomes. Cell 49: 763-774.

Lamond, A.I., M.M. Konarska, P.J. Grabowski, and P.A. Sharp. 1988. Spliceosome assembly involves the binding and release of U4 small nuclear ribonucleoprotein. Proc. Natl. Acad. Sci. 85: 411-415.

Leroy, P., P. Alzari, D. Sasson, D. Wolgemuth, and M. Fellous. 1989. The protein encoded by a murine male germ cell-specific transcript is a putative ATP-dependent RNA helicase. Cell 57: 549-559.

Lin, R.-J., A.J. Lustig, and J. Abelson. 1987. Splicing of yeast nuclear pre-mRNA in vitro requires functional $40 \mathrm{~S}$ spliceosome and several extrinsic factors. Genes \&) Dev. 1: 7-18.

Linder, P. and P.P. Slominski. 1989. An essential yeast protein, encoded by duplicated genes TIF 1 and TIF 2 and homologous to the translation initiation factor eIF-4A, can suppress a mitochondrial missense mutation. Proc. Natl. Acad. Sci. 86: 2286-2290.

Linder, P., P.F. Lasko, M. Ashburner, P. Leroy, P.J. Nielsen, K. Nishi, J. Schnier, and P.P. Slominski. 1989. Birth of the DE-A-D box. Nature 337: 121-122.

Lossky, M., G.J. Anderson, S.P. Jackson, and J. Beggs. 1987. Identification of a yeast snRNP protein and detection of snRNPsnRNP interactions. Cell 51: 1019-1026.

Maniatis, T. and R. Reed. 1987. The role of small nuclear ribonucleoprotein particles in pre-mRNA splicing. Nature 325: 673-678.

Maniatis, T., E.F. Fritsch, and J. Sambrook. 1982. Molecular cloning: A laboratory manual. Cold Spring Harbor Laboratory Press, Cold Spring Harbor, New York.

Moir, D., S.E. Stewart, B.C. Osmond, and D. Botstein. 1982. Cold-sensitive cell-division-cycle mutants of yeast: Isolation, properties, and pseudoreversion studies. Genetics 100: $547-563$.

Nielsen, P.J., G.K. McMaster, and H. Trachsel. 1985. Cloning of eukaryotic protein synthesis initiation factor genes: Isolation and characterization of cDNA clones encoding eIF-4A. Nucleic Acids Res. 13: 6867-6880.

Nishi, K., F. Morel-Deville, J.W.B. Hershey, T. Leighton, and J. Schnier. 1988. An eIF4A-like protein is a suppressor of an Escherichia coli mutant defective in $50 \mathrm{~S}$ ribosomal subunit assembly. Nature 336: 496-498.

1989. Corrigendum: An eIF4A-like protein is a suppressor of an Escherichia coli mutant defective in 50S ribosomal subunit assembly. Nature 340: 246.

Novick, P., B.C. Osmond, and D. Botstein. 1989. Suppressors of yeast actin mutations. Genetics 121: 659-674.

Orr-Weaver, T.L., J.W. Szostak, and R.J. Rothstein. 1981. Yeast transformation: A model system for the study of recombination. Proc, Natl. Acad. Sci. 78: 6354-6358.

Orr-Weaver, T.L., A. Nicolas, and J.W. Szostak. 1988. Gene conversion adjacent to regions of double-strand break repair. Mol. Cell. Biol. 8: 5292-5298.

Padgett, R.A., P.J. Grabowski, M.M. Konarska, S. Seiler, and P.A. Sharp. 1986. Splicing of messenger RNA precursors. Annu. Rev. Biochem. 55: 1119-1150.

Pai, E., W. Kabsch, V. Krengel, K. Holmes, J. John, and A. Wittinghofer. 1989. Structure of the guanine nucleotide binding domain of the Ha-ras oncogene product p21 in the triphosphate conformation. Nature 341: 209-214.

Patterson, B. and C. Guthrie. 1987. An essential yeast snRNA with a U5-like domain is required for splicing in vivo. Cell 49: 613-624.

Pikielny, C.W., B.C. Rymond, and M. Rosbash. 1986. Electrophoresis of ribonucleoproteins reveals an ordered assembly pathway of yeast splicing complexes. Nature 324: 341-345.

Rose, M.D., F. Winston, and P. Hieter. 1989. Methods in yeast genetics. Cold Spring Harbor Laboratory Press, Cold Spring Harbor, New York.

Rossmann, M.G., D. Moras, and K. Olsen. 1974. Chemical and biological evolution of a nucleotide binding protein. Nature 250: 194-199.

Rothblatt, J.A., R.J. Deshaies, S.L. Sanders, G. Daum, and R. Schekman. 1989. Multiple genes are required for proper insertion of secretory proteins into the endoplasmic reticulum in yeast. J. Cell. Biol. 109: 2641-2652.

Rozen, F., I. Edery, K. Meerovitch, T.E. Dever, W.C. Merrick, and N. Sonenberg. 1990. Bidirectional helicase activity of eucaryotic translation initiation factors $4 \mathrm{~A}$ and $4 \mathrm{~F}$. Mol. Cell. Biol. 10: 1134-1144.

Ruby, S.W. and J. Abelson. 1988. An early hierarchic role of Ul small nuclear ribonucleoprotein in spliceosome assembly. Science 242: 1028-1035.

Sachs, A.B. and R.W. Davis. 1990. Translation initiation and ribosomal biogenesis: Involvement of a putative rRNA helicase and RPL46. Science 247: 1077-1079.

Sanger, F., S. Nicklen, and A.R. Coulson. 1977. DNA sequencing with chain-terminating inhibitors. Proc. Natl. Acad. Sci. 74: 5463-5467.

Sawa, H., M. Ohno, H. Sakamoto, and Y. Shimura. 1988. Requirement of ATP in the second step of the pre-mRNA splicing reaction. Nucleic Acids Res. 16: 3157-3164.

Schwer, B. and C. Guthrie. 1991. PRP16 is an RNA-dependent ATPase that interacts transiently with the spliceosome. $\mathrm{Na}$ ture 349: 494-499.

Seraphin, B. and M. Rosbash. 1989. Identification of functional U1 snRNA-pre-mRNA complexes committed to spliceosome assembly and splicing. Cell 59: 349-358.

Seraphin, B., M. Simon, A. Boulet, and G. Faye. 1989. Mitochondrial splicing requires a protein from a novel helicase family. Nature 337: 84-87.

Shannon, K. and C. Guthrie. 1991. Suppressors of a U4 snRNA mutation define a novel U6 snRNP protein with RNA-binding motifs. Genes \& Dev. (in press).

Sharp, P.A. 1987. Splicing messenger RNA precursors. Science 235: 766-771.

Shuster, E.O. and C. Guthrie. 1988. Two conserved domains of yeast U2 snRNA are separated by 945 nonessential nucleotides. Cell 55: 41-48.

Siliciano, P.G., M.H. Jones, and C. Guthrie. 1987a. Saccharomyces cerevisiae has a Ul-like small nuclear RNA with unexpected properties. Science 237: 1484-1487.

Siliciano, P.G., D.A. Brow, H. Roiha, and C. Guthrie. 1987b. An essential snRNA from Saccharomyces cerevisiae has properties predicted for U4, including interaction with a U6-like snRNA. Cell 50: 585-592.

Steitz, J.A., D.L. Black, V. Gerke, K.A. Parker, A. Kramer, D. Frendewey, and W. Keller. 1988. Functions of the abundant U-snRNPs. In Structure and function of maior and minor small nuclear ribonucleoprotein particles (ed. M.L. Birnstiel), pp. 115-154. Springer-Verlag, Berlin.

Tai, P., D. Kessler, and J. Ingraham. 1969. Cold sensitive mutations in Salmonella typhimurium which affect ribosome synthesis. J. Bacteriol. 97: 1298-1304. 
Traub, P. and M. Nomura. 1969. Structure and function of Escherichia coli ribosomes VI. Mechanism of assembly of $30 \mathrm{~S}$ ribosomes studied in vitro. J. Mol. Biol. 40: 391-4l3.

Vijayraghavan, U. and J. Abelson. 1990. PRP18, a protein required for the second reaction in pre-mRNA splicing. Mol. Cell. Biol. 10: 324-332.

Vijayraghavan, U., M. Company, and J. Abelson. 1989. Isolation and characterization of pre-mRNA splicing mutants of Saccharomyces cerevisiae. Genes \&) Dev. 3: 1206-1216.

$\mathrm{Xu}$, Y., S. Petersen-Bjørn, and J.D. Friesen. 1990. The PRP4 (RNA4) protein of Saccharomyces cerevisiae is associated with the $5^{\prime}$ portion of the U4 snRNA. Mol. Cell. Biol. 10: $1217-1225$. 


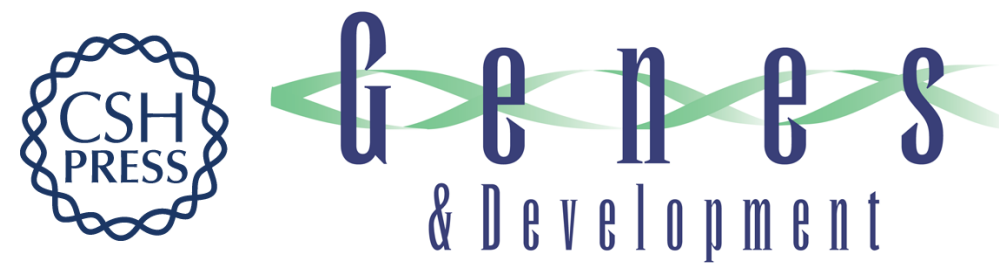

\section{A cold-sensitive mRNA splicing mutant is a member of the RNA helicase gene family.}

E J Strauss and C Guthrie

Genes Dev. 1991, 5:

Access the most recent version at doi:10.1101/gad.5.4.629

References This article cites 72 articles, 32 of which can be accessed free at:

http://genesdev.cshlp.org/content/5/4/629.full.html\#ref-list-1

License

Email Alerting

Service

Receive free email alerts when new articles cite this article - sign up in the box at the top right corner of the article or click here.

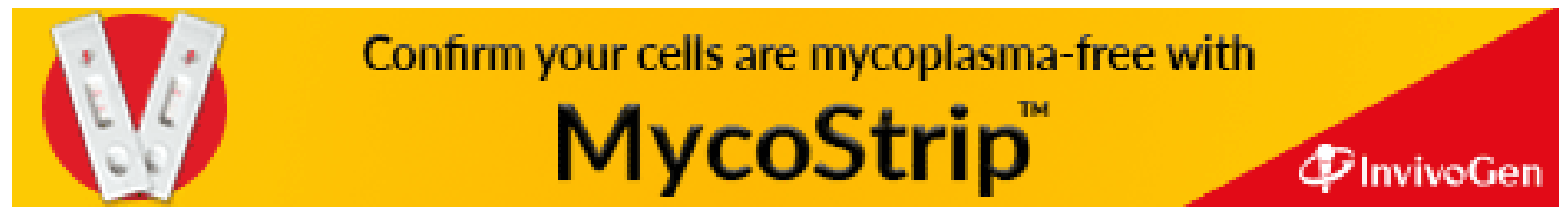

